\title{
Axonal and Schwann Cell BACE1 Is Equally Required for Remyelination of Peripheral Nerves
}

\author{
Xiangyou Hu, ${ }^{1,2}$ Jinxuan Hu, ${ }^{1}$ Lu Dai, ${ }^{1}$ Bruce Trapp, ${ }^{1}$ and Riqiang Yan ${ }^{1}$ \\ ${ }^{1}$ Department of Neurosciences, Lerner Research Institute, Cleveland Clinic, Cleveland, Ohio 44195, and ${ }^{2}$ Department of Anatomy, Anhui Medical \\ University, Hefei 230032, Anhui, People's Republic of China
}

Inhibition of $\beta$-site APP cleaving enzyme 1 (BACE1) is being pursued as a therapeutic target for treating patients with Alzheimer's disease because BACE1 is the sole $\beta$-secretase for generating $\beta$-amyloid peptide. Knowledge regarding the other cellular functions of BACE1 is therefore critical for the safe use of BACE1 inhibitors in human patients. BACE1 deficiency in mice causes hypomyelination during development and impairs remyelination in injured sciatic nerves. Since BACE1 is expected to be ubiquitously expressed, we asked whether axonal or Schwann cell BACE1 is required for optimal remyelination. By swapping sciatic nerve segments from BACE1-null mice with the corresponding wild-type nerve segments or vice versa, we tested how a deficiency of BACE1 in Schwann cells or axons affects remyelination. Our results show that BACE1 in axons and Schwann cells is similarly important for remyelination of regenerated axons. Nerve injury induces BACE1 transcription and protein levels are elevated in Schwann cells. Expression of type I neuregulin 1 (Nrg1), rather than type III Nrg1, was induced by Schwann cells, and the abolished Nrg1 cleavage in BACE1-null Schwann cells contributed to decreased remyelination of regenerated axons. Hence, this study is the first to demonstrate the equal importance of axonal and Schwann cell BACE1 for remyelination of injured nerves.

Key words: BACE1; cell autonomy; neuregulin; remyelination; sciatic nerve transplantation; secretase

\section{Introduction}

$\beta$-site APP cleaving enzyme (BACE1) was initially discovered as a membrane-anchored aspartyl protease for cleaving APP to generate the $\beta$-amyloid (A $\beta$ ) peptide (Hussain et al., 1999; Sinha et al., 1999; Vassar et al., 1999; Yan et al., 1999; Lin et al., 2000). Aberrant accumulation of $A \beta$ is linked to the pathogenesis of Alzheimer's disease (AD; Selkoe, 1994; Tanzi and Bertram, 2005). Mice completely deficient in BACE1 show abolished A $\beta$ production (Cai et al., 2001; Luo et al., 2001; Roberds et al., 2001), confirming that BACE1 is a critical and indispensable protease for $A \beta$ release. Hence, the inhibition of $B A C E 1$ activity is a highly important therapeutic target for treating and preventing $\mathrm{AD}$ (Yan and Vassar, 2014).

As a protease, BACE1 cleaves other cellular substrates in addition to APP. Shortly after the molecular cloning of BACE1, many membrane-anchored proteins, such as the signaling molecules neuregulin-1 (Nrg1; Hu et al., 2006, 2008; Willem et al.,

Received Dec. 22, 2014; revised Jan. 16, 2015; accepted Jan. 23, 2015.

Author contributions: R.Y. designed research;X.H., J.H., and L.D. performed research;X.H., B.T., and R.Y. analyzed data; X.H. and R.Y. wrote the paper.

This study was supported by grants from the National Institutes of Health to R.Y. (Grants NS074256 and AG046929) and to B.T. (Grant NS038186). This study is also partially funded by Grant RG 4012A1/1 from the National Multiple Sclerosis Society to R.Y. We thank Dr. Ran Fan for instructive support on transplantation experiments. We also thank M. Yin (electron microscopy facility at Cleveland Clinic Foundation), for her assistance in electron microscopy, and medical student Joseph Abraham, for his work in the laboratory.

The authors declare no competing financial interests.

Correspondence should be addressed to Dr. Riqiang Yan, Department of Neurosciences, Lerner Research Institute, The Cleveland Clinic, NC30, 9500 Euclid Avenue, Cleveland, OH 44195. E-mail: yanr@ccf.org.

DOI:10.1523/JNEUROSCI.5207-14.2015

Copyright $\odot 2015$ the authors $\quad 0270-6474 / 15 / 353806-09 \$ 15.00 / 0$
2006; Fleck et al., 2013) and Jagged-1 and Jagged-2 (Hu et al., 2013; He et al., 2014), voltage-gated channel proteins such as sodium channel protein $\beta$-subunits (Wong et al., 2005; Kim et al., 2007, 2011), and potassium channel proteins KCNE1 and KCNE2 (Hitt et al., 2010; Sachse et al., 2013), as well as the neural cell adhesion molecule close homolog of L1 (Hitt et al., 2012; Kuhn et al., 2012; Zhou et al., 2012), have been identified as BACE1 substrates. Processing of these substrates by BACE1 has been shown to affect various brain functions, as BACE1 is more profoundly expressed in neurons than in peripheral cells (Vassar et al., 2014).

Among the identified BACE1 substrates, Nrg1 receives considerable attention due to its critical roles in neural and cardiovascular development (Holmes et al., 1992; Mei and Nave, 2014). During development, the binding of axonal Nrg1 to ErbB2/ ErbB3 on Schwann cells or ErbB4 on oligodendrocytes induces phosphorylation of its downstream signaling molecule Akt and regulates myelination (Lemke, 2006). Nrg1 has multiple spliced isoforms, which all have an EGF-like domain for receptor binding, but only types I and III $\beta 1 \mathrm{Nrg} 1$ isoforms are implicated for regulating myelination (Falls, 2003; Nave and Salzer, 2006; Britsch, 2007; Fischbach, 2007; Mei and Xiong, 2008). Both types I and III $\beta 1 \mathrm{Nrg} 1$ isoforms contain BACE1 cleavage sites in their $\mathrm{N}$-terminal regions (Hu et al., 2008; Fleck et al., 2013). Furthermore, both Nrg1 and BACE1 are localized in axons and are transported along axons (Kamal et al., 2001; Park et al., 2001; Lazarov et al., 2005; Buggia-Prévot et al., 2013; Deng et al., 2013). In BACE1-null (BACE1 ${ }^{-/-}$) mice, Nrg1 is no longer cleaved at this site by BACE1, and this abrogated cleavage appears to cause hypomyelination in peripheral and central nerves during mouse 

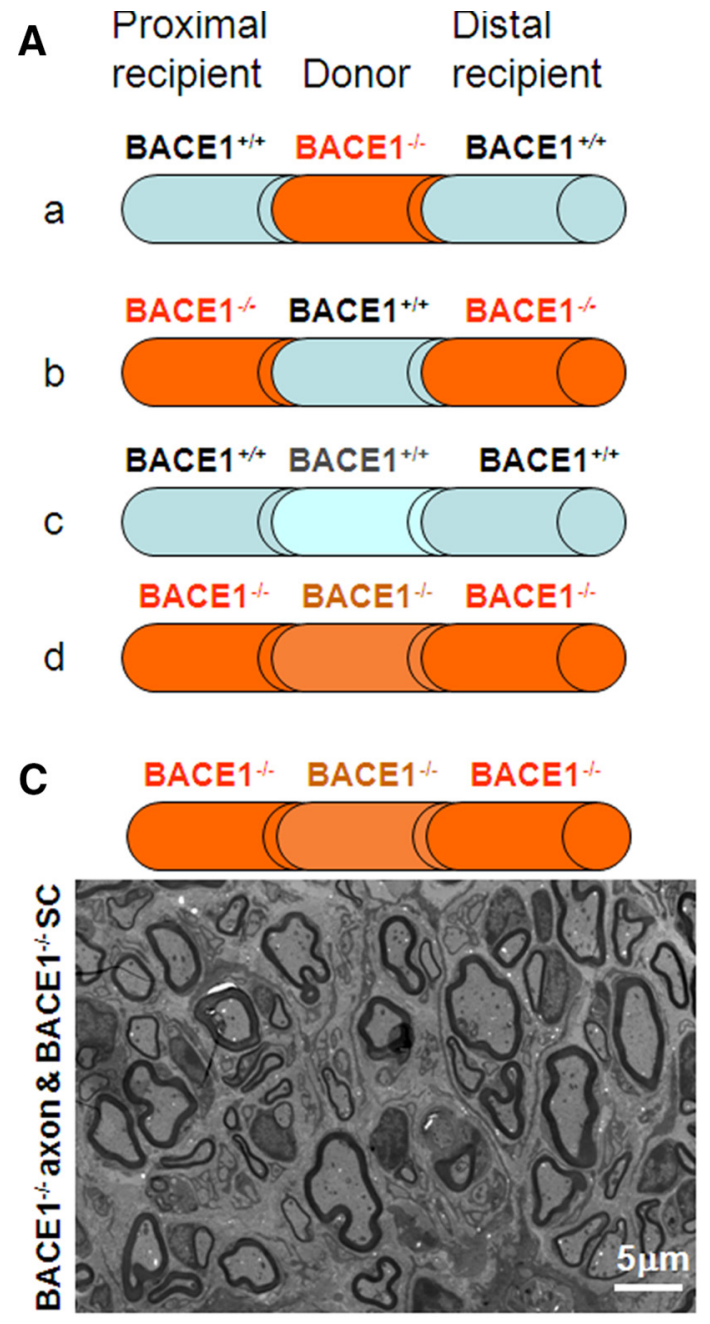

B

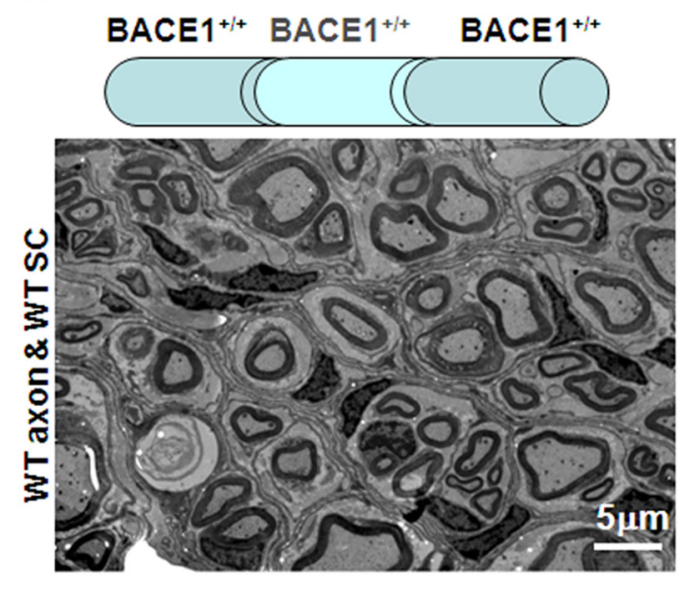

D

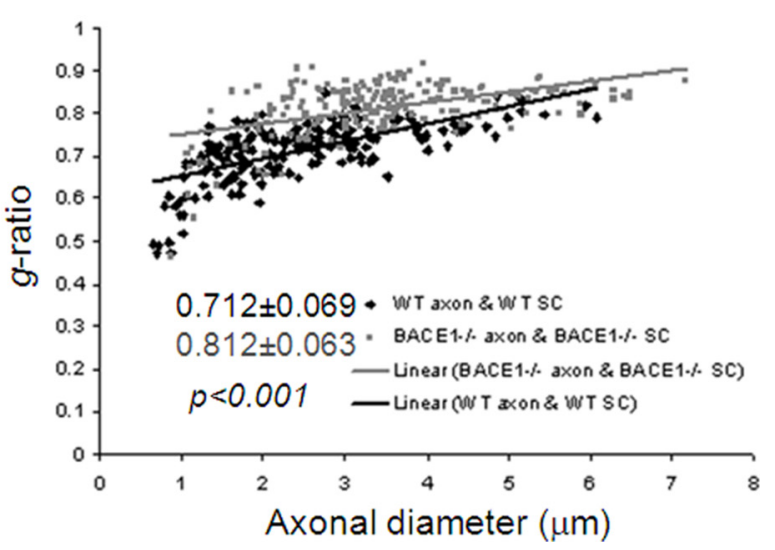

Figure 1. Nerve transplantation within the same mouse genotype. $A$, Schematic illustration of nerve transplantation among different genotypes of mice. The transplanted nerve segment (8 mm) is flanked by the proximal and distal segments, and is indicated by a different color. The genotype of each segment is specified. $\boldsymbol{B}, 0$ ne nerve segment from a WT mouse was transplanted into another WT recipient. After 8 weeks of recovery, mice were fixed for electron microscopy. Fixed sciatic nerves were dissected out, and the segment within the transplanted region was used for visualizing myelin sheath thickness. C, D, One BACE1-null nerve segment was similarly replaced by another BACE1-null segment. The relative thickness of the myelin sheath can be compared based on $\mathrm{g}$-ratio calculations. A scatterplot of the g-ratios of remyelinated axons shows quantitative evidence of hypomyelination in the transplanted nerves. Scale bar, $5 \mu \mathrm{m}$.

development (Hu et al., 2006; Willem et al., 2006) and impaired remyelination following nerve injury (Hu et al., 2008).

Although earlier studies suggest that axonal Nrg1 is required for optimal myelination (Michailov et al., 2004; Taveggia et al., 2005, 2008; Tao et al., 2009), the potential contribution of BACE1 in myelinating cells to proper myelination has never been investigated, especially considering the fact that BACE1 is ubiquitously expressed. To address this question, we performed nerve transplantation experiments by swapping sciatic nerve Schwann cells from BACE1-null mice with those of wild-type (WT) mice, and vice versa according to well established procedures (Aguayo et al., 1976; Haney et al., 1999). After comparing the myelin sheath thickness of transplanted sciatic nerves, we discovered that BACE1 in axonal and Schwann cells was equally important for optimal remyelination, as lacking either source of BACE1 impaired remyelination. Hence, this study is the first to provide evidence that optimal remyelination requires Schwann cell BACE1. As such, non-neuronal BACE1 and its substrates contribute significantly to nerve functions.

\section{Materials and Methods}

Transplantation procedure. BACE1-null mice were generated as described in the original publication (Cai et al., 2001). For myelination studies, BACE1-null mice were backcrossed to C57BL/6 mice for more than eight generations and maintained in this genetic background. Transplantation procedures were first described and submitted for approval by the Institutional Animal Care and Use Committee at the Lerner Research Institute, in compliance with the guidelines established by the Public Health Service Guide for the Care and Use of Laboratory Animals. Briefly, under deep anesthesia, sciatic nerve segments ( $8 \mathrm{~mm}$ long) were removed from donor mice. Sciatic nerves of recipient mice were transected at mid-thigh level, and the donor segments were microsutured into the gap. Surgery was performed under sterile conditions, and mice were housed in a sterile environment until they were killed 8 weeks after transplantation. For WT or BACE1-deficient recipient mice of either sex, cyclosporin A was injected daily at a dose of $17 \mathrm{mg} / \mathrm{kg}$ for immunosuppression, which does not affect nerve regeneration. At 8 weeks after surgery, mice were perfused with $4 \%$ formaldehyde fixative, and the proximal transplanted graft and distal segments identified by the presence of microsutures were dissected out. Each portion of the nerve was embedded 
A BACE1 $1^{+/+}$BACE1 $\%$ BACE1 ${ }^{+/+}$
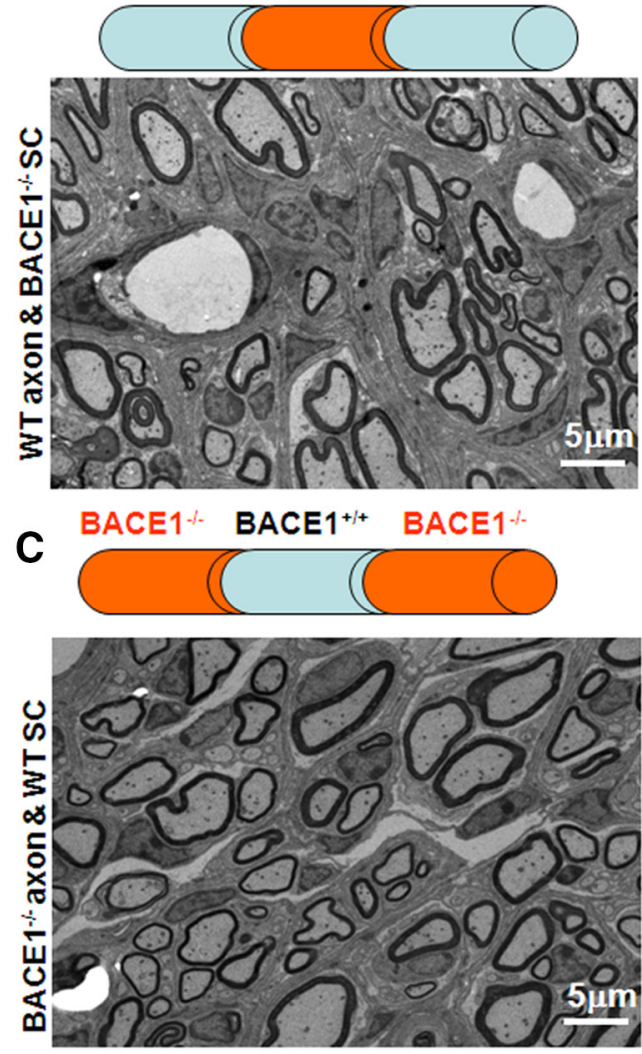

B

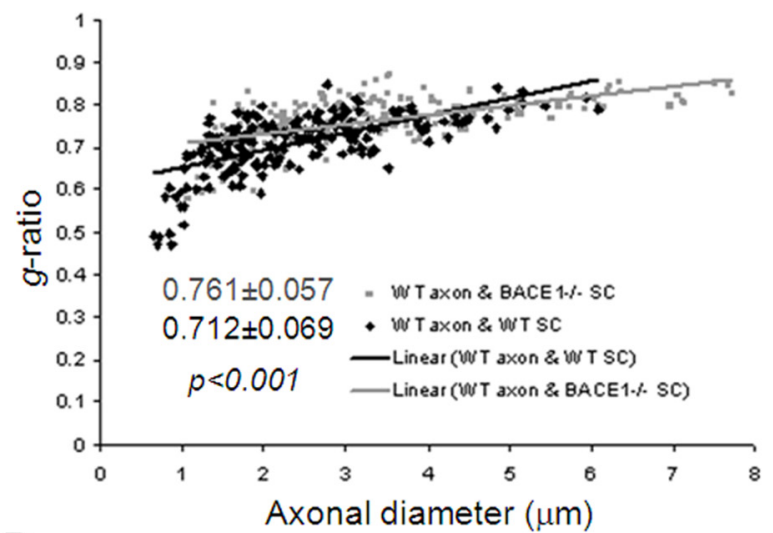

D

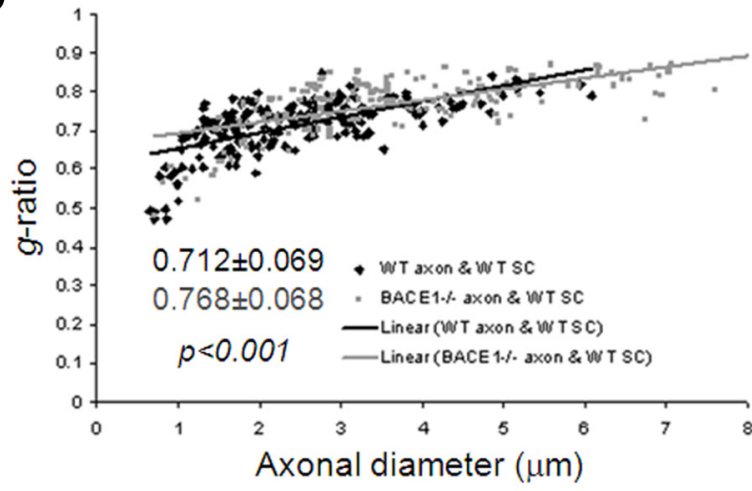

$\mathbf{E}$

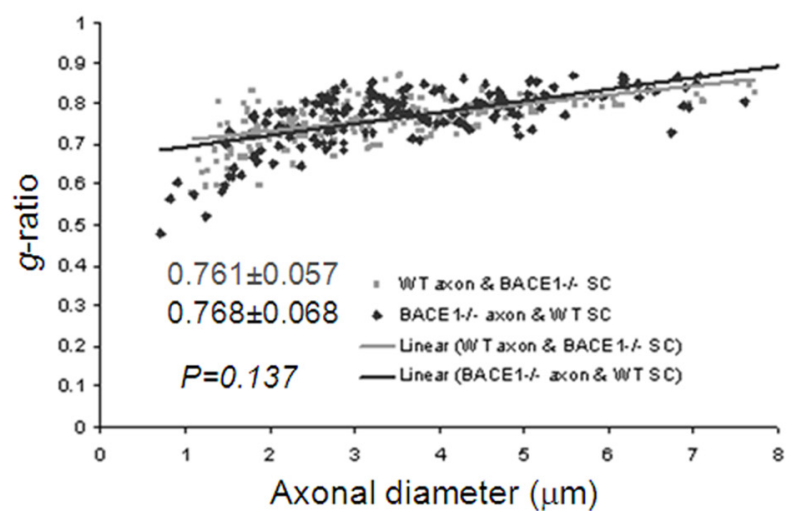

Figure 2. Nerve transplantation between wild-type and BACE1-null mice. $A, C$, A nerve segment from a BACE1-null mouse was transplanted into the same region of a WT sciatic nerve ( $A$ ) or vice versa (C). The fixed nerve segments were examined by electron microscopy to compare the thickness of the myelin sheath. $\boldsymbol{B}, \boldsymbol{D}, \boldsymbol{E}, \mathrm{A}$ scatterplot of the g-ratio of the correspondingly indicated segment was calculated and compared with that from WT controls. Scale bar, $5 \mu \mathrm{m}$.

and analyzed by electron microscopy (EM), as described below, to provide g-ratios (sheath thickness relative to axon diameter), myelin thickness, and numbers of myelinated axons. When used for Western blot analysis, dissected segments were subjected to protein extraction (see Western blotting and antibodies).

Western blotting and antibodies. Proteins were extracted from WT and BACE1-null mice in radioimmunoprecipitation buffer [50 $\mathrm{mm}$ Tris- $\mathrm{HCl}$ at $\mathrm{pH} 7.4,1 \% \mathrm{NP} 40,0.25 \%$ sodium deoxycholate, $150 \mathrm{~mm}$ $\mathrm{NaCl}, 1 \mathrm{~mm}$ EDTA, $1 \mathrm{~mm} \mathrm{NaF}, 1 \mathrm{~mm} \mathrm{Na} 3 \mathrm{VO} 4$, and a protease inhibitor cocktail (Roche)]. Equal amounts of protein $(50 \mu \mathrm{g})$ were resolved on a NuPAGE Bis-Tris gel (Invitrogen) and transferred onto nitrocellulose membranes (Invitrogen) for Western blot analysis. HRPconjugated secondary antibodies were used and visualized using enhanced chemiluminescence (Thermo Scientific). TuJ1 (1:1000) was purchased from Biolegend. GFAP (1:1000) and $\beta$-actin $(1: 10,000)$ were purchased from
Sigma. Type I neuregulin-1 antibody (1:200) was purchased from Santa Cruz Biotechnology.

Morphological analyses. For confocal experiments, 4\% paraformaldehyde-fixed frozen nerve tissues from the indicated genotypes of mice were cut on a cryostat (Microm International GmbH). Serial $12 \mu \mathrm{m}$ sections were immunostained with specific primary antibodies. After washing with PBS three times, sections were incubated with the secondary antibody goat anti-mouse or anti-rabbit IgG (1:400) conjugated with Alexa Fluor 488 or 568 (Invitrogen). For EM experiments, animals were first subjected to transcardial perfusion with $4 \%$ paraformaldehyde and $2.5 \%$ glutaraldehyde for fixation. Sciatic nerves were then surgically removed and immersed in fixative solution overnight at $4^{\circ} \mathrm{C}$, and then processed for EM examination.

Quantification of g-ratios. The g-ratios of axons from the sciatic nerve were determined as previously described (Hu et al., 2006). ImageJ soft- 

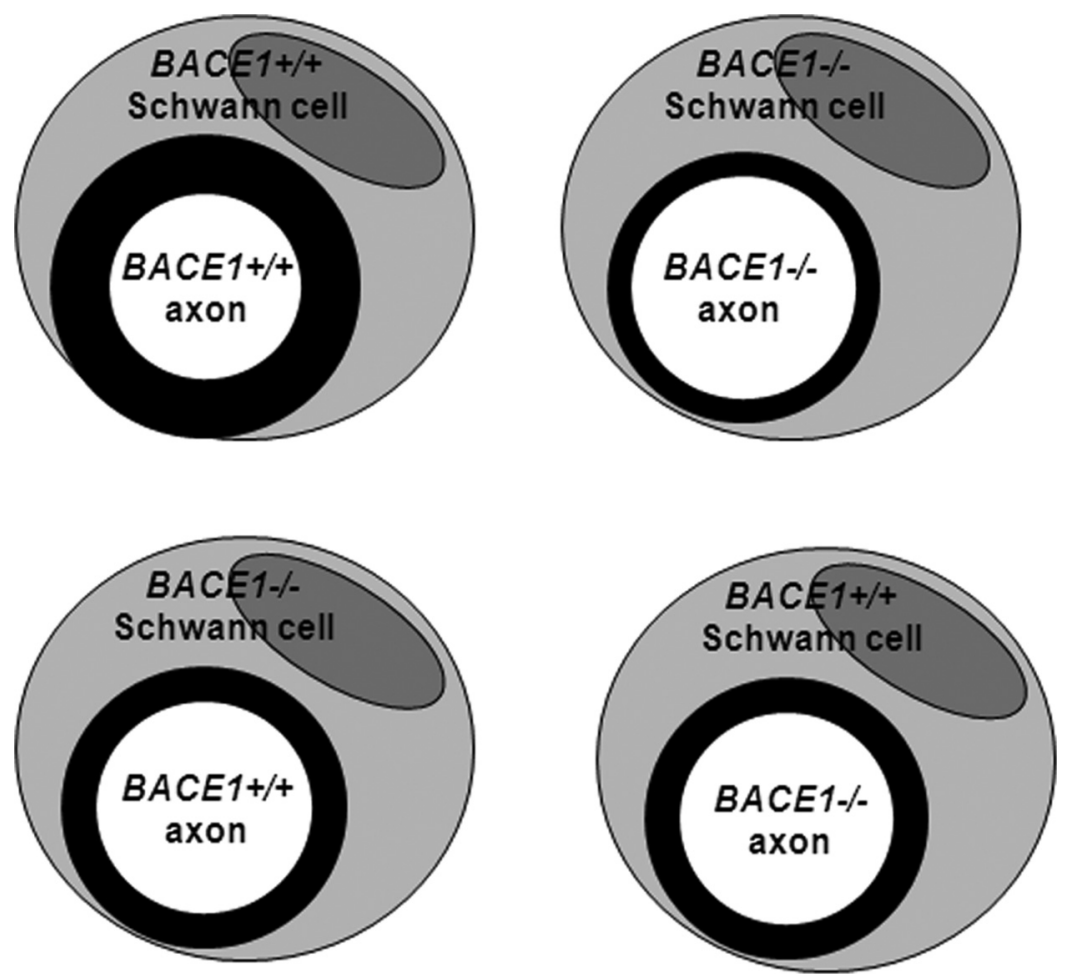

Figure 3. Observed myelin sheath thickness in transplanted nerve. Schwann cell and the nucleus are depicted in large circles. Part of the Schwann cell plasma forms the myelin sheath (shown in black circle) that wraps around axons. The thickness of the inner circles represents the thickness of the myelin sheath.

ware (NIH Image; National Institutes of Health) was used for digital tracing. The myelinated axonal diameter and circumference were measured by digitally tracing the inner and outer layers of the myelinated fiber. The g-ratio was calculated by dividing the inner circumference of the axon (without myelin) by the outer circumference of the total fiber (including myelin). The g-ratio data are displayed as a scatterplot against axon diameter.

In situ hybridization. Total RNA was extracted from WT mouse hippocampal tissue using TRIzol Reagent (Invitrogen). The extracted RNA was subsequently digested with an RNase-free DNase I (Sigma) before RT-PCR. Single-stranded cDNA was synthesized from total RNA using the High Capacity cDNA Reverse Transcription Kit (Life Technologies). DNA templates for BACE1, type I Nrg1, and type III Nrg1 containing the sequences of T7 and T3 promoters were produced by PCR using the Expand High Fidelity PCR System (Life Technologies). The primers were selected as BACE1_249 (forward primer: AATCAGTCCT TCCGCATCAC; reverse primer: AACAAACGGACCTTCCACTG), type I Nrg1_194 (forward primer: AAGAAGAAGGACCGGGGA; reverse primer: TCAGCTCATTCCCGTTCTT), and type III Nrg1_268 (forward primer: GCCAGGACCCTGTTATTT; reverse primer: GTTCCTGACTTGGGTGT). Forward primers had a T3 sequence inserted into the 5 ' end (AATTAACCCTCACTAAAGGG), and reverse primers had a T7 sequence inserted into the $5^{\prime}$ end (TAATACGACTCACTATAGGG). There was no cross talk between T3 and T7. The promoters could be included in the same DNA fragment, enabling the synthesis of both sense and antisense cRNA probes from the same DNA fragment. Antisense and sense cRNA probes labeled with DIG were synthesized using DIG RNA Labeling Kit (Roche).

Statistical analyses. Statistical analyses were performed using Microsoft Excel software. All data were analyzed for statistical significance using an $F$ test for equal variance followed by a two-tailed Student's $t$ test or verified by ANOVA. Significant $p$ values are denoted by the use of asterisks in the text and figures $\left({ }^{*} p<0.01\right)$. All data values are expressed as the mean \pm SEM.

\section{Results \\ Remyelination of sciatic nerves after nerve transplantation}

Injured sciatic nerves will normally be regenerated and remyelinated by Schwann cells during recovery. We have previously shown that BACE1 deficiency in mice impairs remyelination of sciatic nerves and that regenerated axons in these mice are hypomyelinated (Hu et al., 2008). Here, we investigated the question of whether this hypomyelination is due to a deficiency of BACE1 in axons and/or in Schwann cells. To answer this question of cell autonomy, we transplanted an $8 \mathrm{~mm}$ donor sciatic nerve segment into a recipient mouse, as illustrated in Figure 1A. In such a transplantation experiment, axons and myelin rapidly degenerate in the grafted segment and in the recipient distal nerve stump due to Wallerian degeneration. This nerve injury induces Schwann cells native to each nerve segment to divide and to occupy the basal laminae by forming "Schwann tubes." Regenerating axons from the proximal stump grow into and along these Schwann tubes within the grafted segment, associating with Schwann cells from the donor animal, and then into Schwann tubes in the distal stump. During nerve regeneration, the same set of axons is remyelinated within the graft by donor Schwann cells and in the distal stump by recipient Schwann cells. After 8 weeks of postsurgical recovery, the donor segment was examined for axonal regeneration and myelin sheath thickness by electron microscopy.

We showed that transplantation of one WT nerve segment into another WT recipient resulted in nerve regeneration and remyelination (Fig. $1 B$ ). When a BACE1 ${ }^{-/-}$nerve segment was similarly transplanted into another $\mathrm{BACE} 1^{-1-}$ mouse recipient, remyelination also occurred, but the myelin sheath thickness was clearly reduced (Fig. $1 C$ ). The calculated g-ratio was $0.712 \pm$ 0.069 in the WT $\rightarrow$ WT swap ( $n=184$ axons) versus $0.812 \pm$ 0.063 in the BACE $1^{-1-} \rightarrow$ BACE $^{-1-}$ swap $(n=204$ axons; Fig. $1 D ; p<0.001$, Student's $t$ test). These parameters from the same genotyping swaps would then serve as controls for the subsequent comparisons.

For a BACE1-null nerve segment transplanted into a WT mouse recipient $\left(\mathrm{BACE} 1^{-1-} \rightarrow \mathrm{WT}\right.$ ), the regenerated axon was extended from the WT proximal segment into the BACE1 ${ }^{-1-}$ Schwann tube and beyond during the recovery stage. Axons regenerated from the WT proximal stump were remyelinated from the transplanted BACE1 ${ }^{-1-}$ Schwann cells (Fig. 2A). However, they were less effectively ensheathed when compared with that from WT $\rightarrow$ WT transplantation, as the g-ratio was increased to $0.761 \pm 0.057$ (Fig. $2 B ; n=221$ axons, $p<0.001$ ). This observation suggests that $\mathrm{BACE} 1^{-1-}$ Schwann cells did not have the same remyelination capacity as WT Schwann cells. This observation would not be expected if axonal BACE1 is exclusively critical for remyelination, as BACE1 is fully functional in axons. In the reverse transplantation experiment (WT $\rightarrow$ BACE $1^{-1-}$ ), remyelination was also less effective when compared with WT $\rightarrow$ WT transplantation (Fig. 2C) and the 

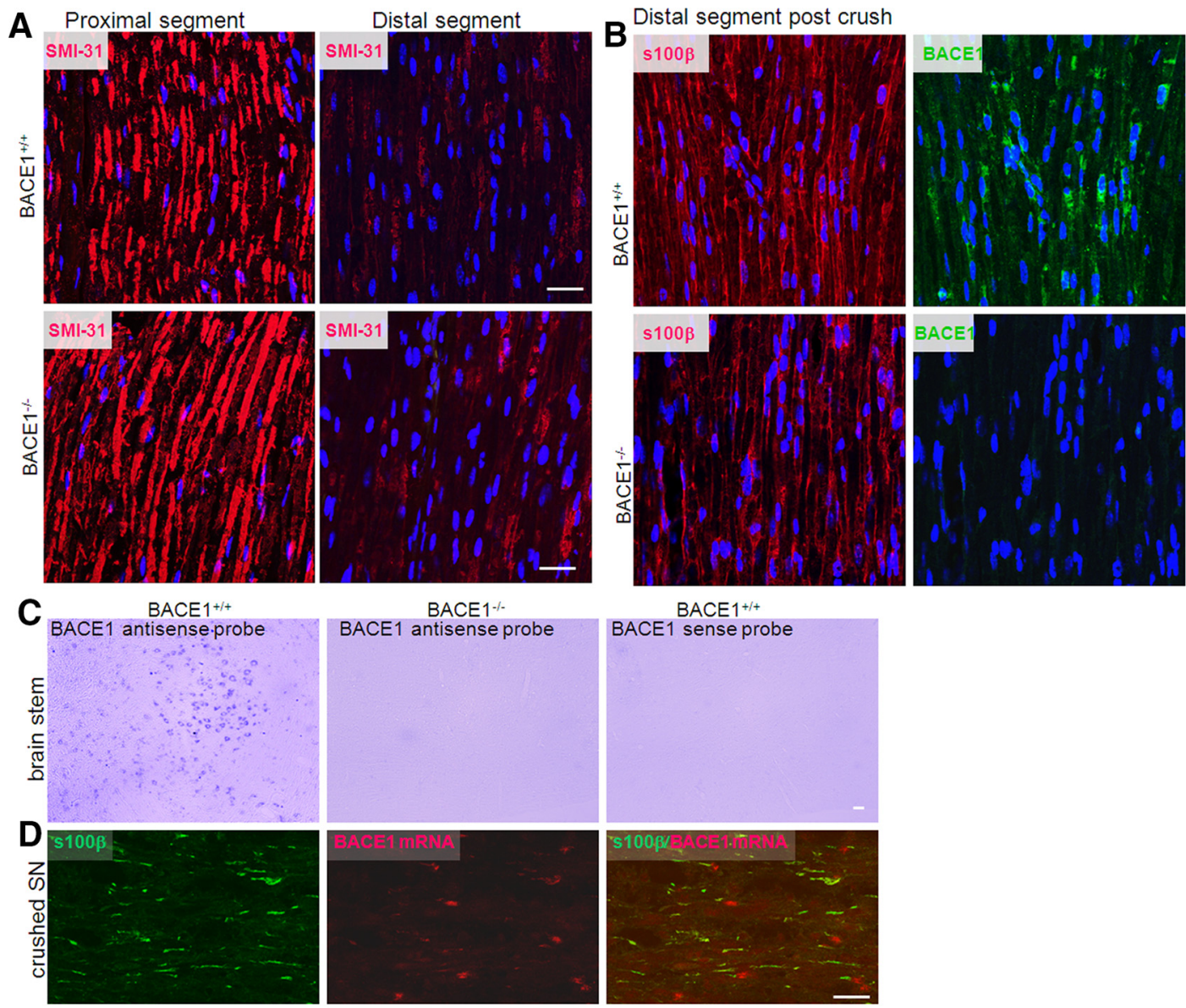

BACE $1^{-1}$
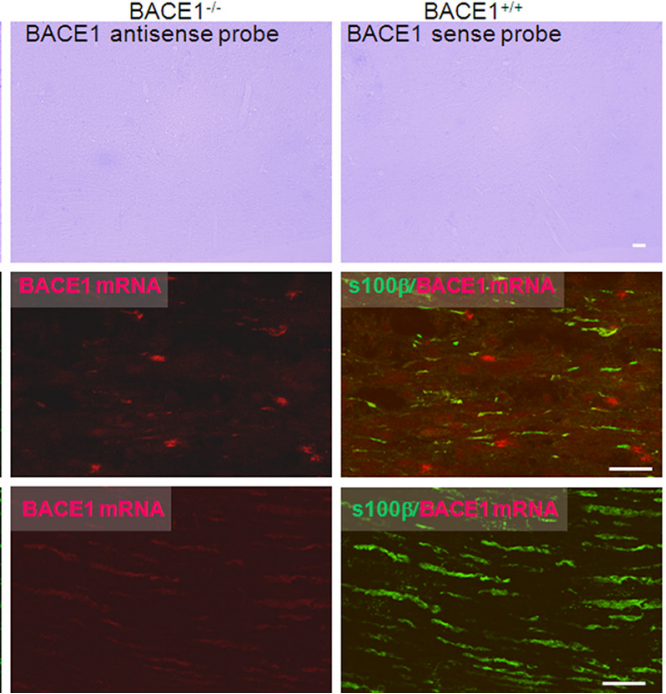

Figure 4. Expression of BACE1 in Schwann cells. $A$, Mouse sciatic nerves were crushed, followed by $3 \mathrm{~d}$ of recovery. Then injured nerves were dissected out for confocal microscopy. Monoclonal antibody Smi-31 was used to label axons. $\boldsymbol{B}$, Mice with similarly injured nerves were allowed to recover for $5 \mathrm{~d}$, and fixed nerves were dissected out for confocal analyses. An antibody specific to $5100 \beta$ was used to mark Schwann cells. An antibody specific to BACE1 was used to verify the expression of BACE1 in Schwann cells. C, $\boldsymbol{D}$, Brain samples (C) and crushed nerve samples (D) were used for in situ hybridization to detect BACE1 mRNA expression. Antisense probe was used to detect BACE1 mRNA, while the sense probe was used as a negative control. BACE1-null samples were used to verify specific hybridization to the BACE1 mRNA. Scale bars: $A, B, 30 \mu \mathrm{m} ; C, D, 20 \mu \mathrm{m}$.

g-ratio of the donor segment was $0.768 \pm 0.068$ (Fig. $2 D ; n=$ 161 axons; $p<0.001)$.

The g-ratios in the two different swapping conditions were almost identical (Fig. 2E; $p=0.137$, Student's $t$ test), implying that a lack of BACE1 in either axons or Schwann cells was sufficient to significantly affect remyelination. As illustrated in Figure 3, BACE1 in both Schwann cells and axons appears to play an equally important role for optimal remyelination.

\section{Induced expression of BACE1 in Schwann cells}

If both sources of BACE1 in sciatic nerves are necessary for properly ensheathing regenerated axons, it is important to confirm whether BACE1 is truly expressed by Schwann cells. Three lines of experiments were conducted to validate BACE1 expression in Schwann cells. First, we cultured Schwann cells from both WT and BACE1-null postnatal day 5 mouse sciatic nerves and examined BACE1 expression in protein lysates. BACE1 in this Western blot preparation was barely detected in WT Schwann cells (data not shown). Nevertheless, we could not completely exclude re- sidual fibroblast cells contained in the cultures as potential sources of BACE1.

We then conducted nerve crush experiments in which distal axons normally degenerate shortly after injury, while Schwann cells remain in the distal segments. Using confocal microscopy, we showed that axons labeled by SMI-31 were largely degenerated $3 \mathrm{~d}$ after nerve crush, while axons in proximal segments remained intact (Fig. 4A), confirming similar levels of Wallerian degeneration between the two genotypes of mice. Axons in all examined distal segments were almost completely removed $5 \mathrm{~d}$ following nerve crush (data not shown), which is consistent with our prior observations (Hu et al., 2008). Schwann cells labeled by $\mathrm{S} 100 \beta$ antibody, on the other hand, similarly remained in both WT and BACE1-null distal segments (Fig. 4B). BACE1 was clearly detected in WT, but not in BACE1-null, Schwann cells (Fig. 4B). Therefore, both sets of experiments suggested the expression of BACE1 by Schwann cells.

To further verify this observation, we conducted in situ hybridization experiments to detect BACE1 mRNA in Schwann cells. To ensure specific expression, we first examined brain sam- 

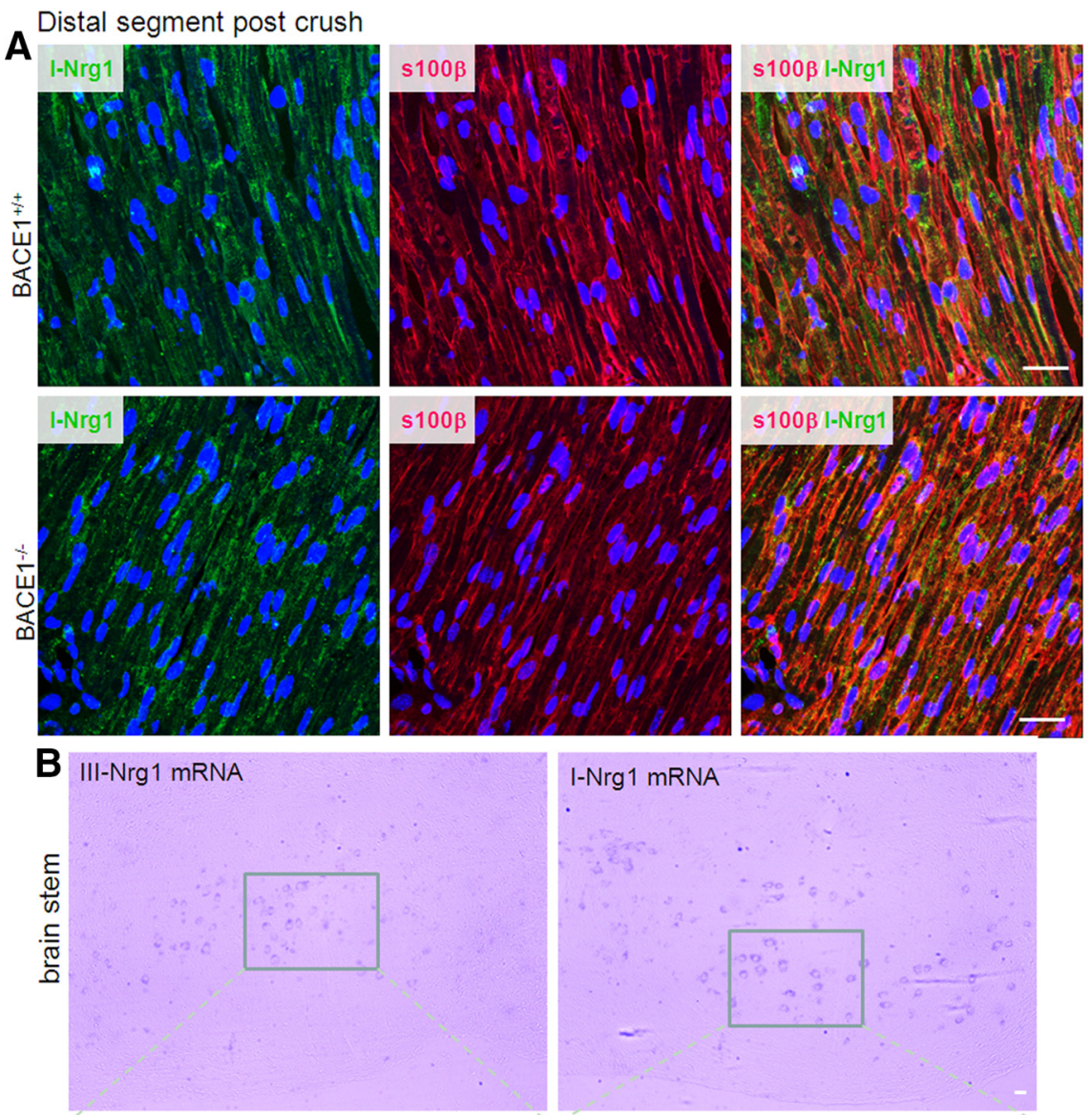

I-Nrg1 mRNA
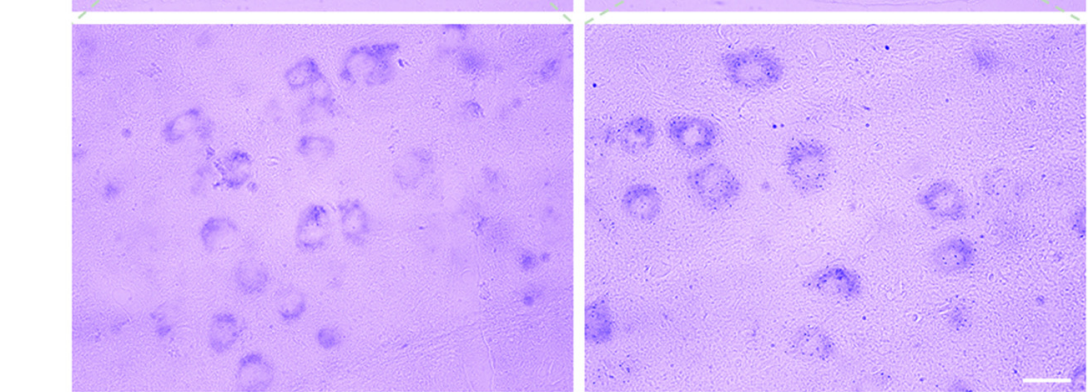

C
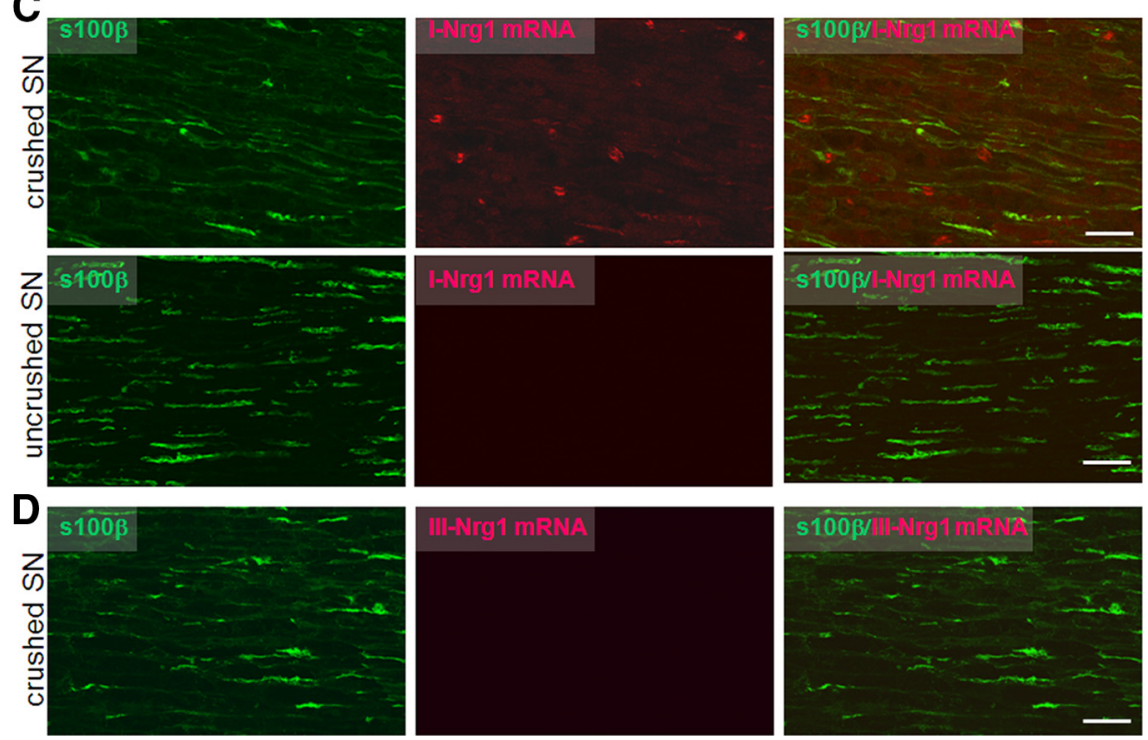

Figure 5. Expression of type I Nrg1 (I-Nrg1) but not type III Nrg1 (III-Nrg1) by Schwann cells. $A$, The distal segments from crushed sciatic nerves were used for staining with an antibody specific to I-Nrg1 in green and s100 $\beta$ in red for Schwann cells. $B_{\text {, }}$ ples by using two different BACE1 antisense probes. As expected, BACE1 mRNA was predominantly expressed in WT neurons, but not in BACE1-null neurons, as detected by two different antisense probes (see example in Fig. $4 C$ ); reversely transcribed sense probes were negative. Using the nerve crush samples, we clearly observed BACE1 mRNA in Schwann cells, which were labeled by $\mathrm{S} 100 \beta$ (Fig. $4 D$ ). On the other hand, BACE1 mRNA was not readily detected in the proximal segments. Hence, we showed that the expression of BACE1 in Schwann cells can be induced in response to injury.

\section{Differential expression of neuregulin-1 in Schwann cells}

To explore potential BACE1 substrates contributing to remyelination, we examined the expression of Nrg1 in Schwann cells, as this is a validated BACE1 substrate and is important for myelination (Nave and Salzer, 2006). Confocal staining results showed that type I Nrg1 was strongly expressed by Schwann cells after nerve crush in both WT and BACE1-null samples (Fig. $5 A$ ), which is consistent with the notion that Wallerian degeneration induces de novo expression of type I Nrg1 in Schwann cells (Stassart et al., 2013). Interestingly, the commercial antibody for detecting type III Nrg1 expression was also positive in Schwann cells from both genotypes of mouse samples, although its expression was weaker (data not shown).

To confirm Nrg1 expression in Schwann cells, we conducted similar in situ hybridization experiments to detect mRNA expression. In brain, both types I and III Nrg1 were similarly expressed by neurons (see examples of brainstem samples in Fig. $5 B)$. In crushed sciatic nerve samples, type I Nrg1 mRNA was clearly detected by the antisense probe but not by the sense probe (Fig. $5 C$ ). In the proximal segment, type I Nrg1 was not detectable, suggesting that the transcription of type I Nrg1 mRNA was also induced due to nerve injury. Consistent with a prior report (Stassart et al., 2013), type III Nrg1 mRNA was not

Antisense probes for I-Nrg1 and III-Nrg1 were generated for detecting types I and III Nrg1 mRNA in mouse brains. Enlarged views show staining of the probes in neuronal cytoplasm. Neurons from 2-month-old mouse brainstem appear to similarly express both types of $\mathrm{Nrg} 1$. Sense probes failed to detect any signals and were not shown. $C, D$, Crushed nerve samples from the distal and proximal segments were used for detecting types I and III Nrg1. Expression of type I Nrg1 was clearly elevated in Schwann cells, while type III Nrg1 mRNA was not detectable. Scale bars: $\boldsymbol{A}, \boldsymbol{B}, 30 \mu \mathrm{m} ; \boldsymbol{C}, \boldsymbol{D}, 20 \mu \mathrm{m}$. 


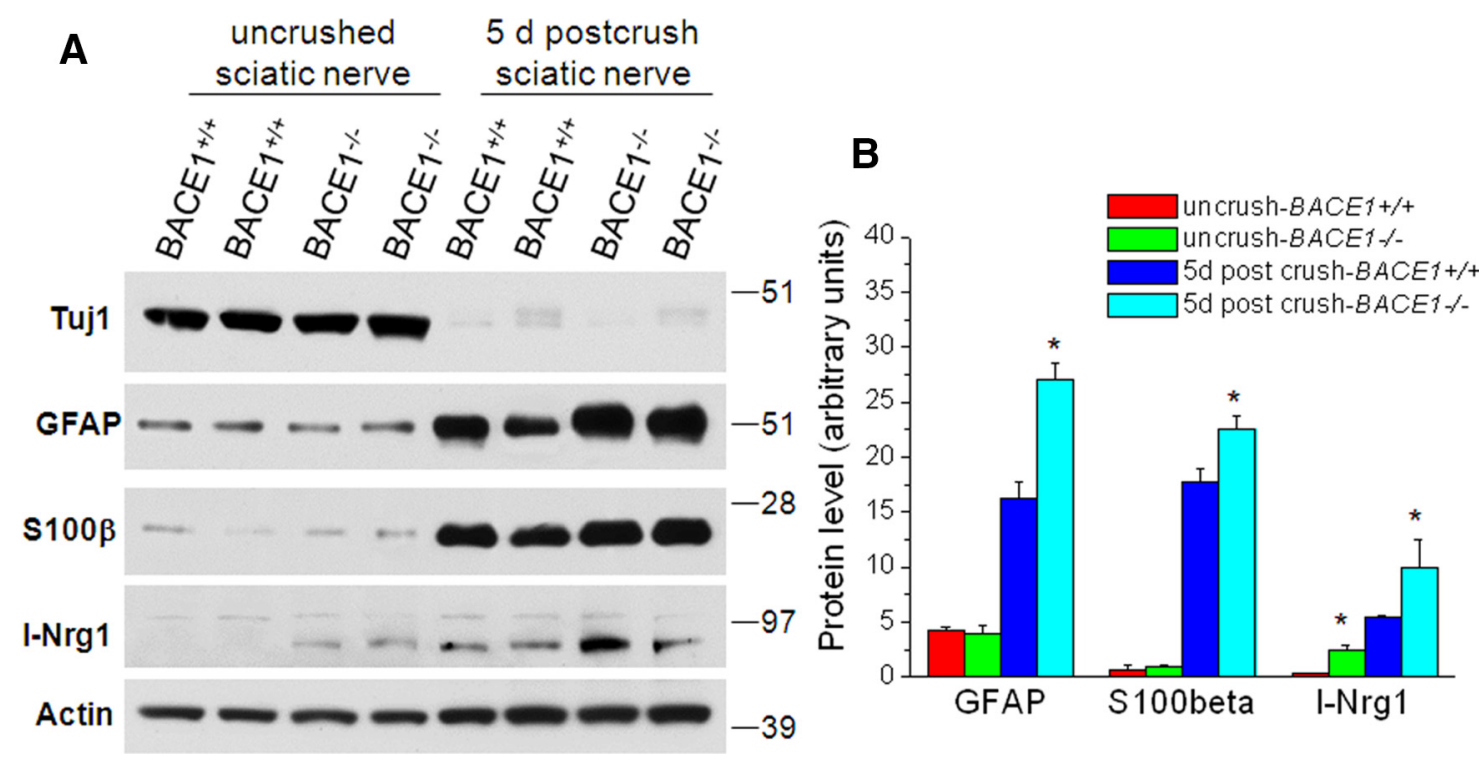

Figure 6. Expression of $\mathrm{Nrg} 1$ in Schwann cells after nerve injury. $A$, Sciatic nerve segments were dissected out from the indicated genotypes of mice for the preparation of protein lysates. Equal amounts of protein from each sample were loaded for Western blot analyses. Actin antibody was used to detect $\beta$-actin to serve as a loading control. $\boldsymbol{B}$, Bar graphs show expression of the indicated proteins, which were normalized to the $\beta$-actin loading control. $N=2$ in each group, and three separate experiments were conducted. ${ }^{*} p<0.01$, ANOVA test.

detected in Schwann cells (Fig. 5D). Hence, nerve crush induces differential expression of $\mathrm{Nrg} 1$ isoforms, and type I Nrg1 is predominantly expressed in Schwann cells.

\section{Cleavage of type I Nrg1 by BACE1}

After sciatic nerve crush and $5 \mathrm{~d}$ of recovery, protein levels as measured by GFAP and $s 100 \beta$ were significantly elevated (Fig. $6 A)$, reflecting that Schwann cells in the distal segments were actively proliferating in response to Wallerian degeneration. To determine whether Nrg1 processing was affected in BACE1-null mice, we examined protein levels of Nrg1 in $5 \mathrm{~d}$ post-crushed distal sciatic segments, which contain mainly Schwann cells, while axons are already degenerated. Clearly, full-length Nrg1 was elevated in BACE1-null segments compared with the corresponding segments in WT mice (Fig. 6A), indicating an abrogated cleavage of Nrg1 by BACE1. A separate recent study (Stassart et al., 2013) showed that loss of axonal contact triggers denervated Schwann cells to transiently express Nrg1, and suggests that type I Nrg1 serves as an autocrine/paracrine signal to promote Schwann cell differentiation and remyelination. Together, these results support this notion that BACE1 cleaves Nrg1 in Schwann cells and secreted Nrg1 N-terminal fragments by producing autocrine signals for myelination.

\section{Discussion}

Proper myelination and remyelination after nerve injury are critical for salutatory conduction. The thickness of the myelin sheath is tightly controlled by instructive signals. It has always been an actively investigated topic as to whether the instructive signals come from axons and/or from Schwann cells in the peripheral nervous system. The collective prior and current results clearly show that axonal type III Nrg-1 is required for developmental myelination but that type I Nrg1 is likely required for remyelination after nerve injury. Proteolytic cleavage of $\mathrm{Nrg} 1$ to release the EGF-containing N-terminal domain is essential for mediating the Nrg1-ErbB2/3 signaling cascade, and BACE1 is present in both axons and Schwann cells to execute this cleavage.
BACE1, as a type I transmembrane aspartyl protease, cleaves Nrg-1 at the ectodomain Phe-Met site, which is evolutionarily conserved, is present only in the $\beta 1$ isoforms, and is shared by type III Nrg1 (Hu et al., 2008). BACE1 may also cleave an additional site within the $\mathrm{N}$-terminal side of type III Nrg1 to release an EGF-containing domain (Fleck et al., 2013). Although Nrg1 can also be shed by ADAM10 and ADAM17 (La Marca et al., 2011; Luo et al., 2011), the cleavage of Nrg1 by BACE1 is more critical for AKT activation, as demonstrated by observations in BACE1null mice and chemical inhibition. Earlier studies demonstrated that axonal type III Nrg1 and BACE1 are both richly expressed by neurons (Vassar et al., 2009; Liu et al., 2011) and that instructive signals from axonal type III Nrg1 are critical for myelination (Nave and Salzer, 2006). For remyelination, axonal type III Nrg1 does not appear to be necessary (Fricker et al., 2013). Contrary to expectations, we found that both axonal and Schwann cell BACE1 are equally important for optimal remyelination of injured sciatic nerves.

BACE1 in normal Schwann cells was barely detectable. Intriguingly, nerve injury significantly induced the transcription of BACE1 and the expression of BACE1 protein (Fig. $4 B, D$ ). Such an induction is likely associated with its necessity for ensheathing remyelinated axons. How BACE1 transcription is induced remains to be investigated, but BACE1 is known as a stress-induced protease, and inflammation can induce the transcription of BACE1 (Chami and Checler, 2012). Transcription and translation of its substrate type I Nrg1, but not type III Nrg1, is similarly enhanced (Fig. 5). A recent study (Stassart et al., 2013) showed that mutant mice lacking a functional Nrg1 gene in Schwann cells are fully myelinated but exhibit impaired remyelination following injury. The induction of both protease and its substrate appears to provide enhanced signaling initiated from a Nrg1soluble fragment to mediate an autocrine instruction for remyelination, and this enhancement is consistent with the reported need of the Nrg1 gene in Schwann cells. We indeed found cleavage of Nrg1 by BACE1 in Schwann cells, as the level of full-length Nrg1 was elevated in BACE1-null Schwann cells within distal 
segments (Fig. 6). It is likely that decreased Nrg1 signaling activity in Schwann cells contributes to reduced remyelination.

Despite the important contribution of Schwann cell $\mathrm{Nrg} 1$ to remyelination, we still do not know the answer to why axonal and Schwann cell BACE1 provides similar contributions to the remyelination of injured sciatic nerves. Axonal Nrgl is not essential for remyelination based on a study using a conditional $\mathrm{KO}$ mouse model (Fricker et al., 2013), despite its indispensable role in myelination during early development. Axonal BACE1 is clearly required for optimal remyelination, as WT Schwann cells failed to wrap BACE1-null or WT regenerated axons equally (Fig. 2A). Perhaps, another molecular BACE1 substrate in BACE1-null regenerated axons may contribute to remyelination. For example, we cannot totally exclude the contribution of $\mathrm{Nrg} 3$ signaling activity to remyelination, as axonal $\mathrm{Nrg} 3$ is cleavable by BACE1 to activate ErbB receptors on Schwann cells (Hu et al., 2008). Alternatively, another unidentified BACE1 substrate may be important for this remyelination, and investigation of this will require future studies.

In summary, we have demonstrated that BACE1 from both axonal and Schwann cells is required for remyelination of regenerated axons, and that Nrg1 in both axons and Schwann cells differentially contributes to remyelination. Our future studies will explore whether chemical inhibition of BACE1 similarly affects remyelination.

\section{References}

Aguayo AJ, Charron L, Bray GM (1976) Potential of Schwann cells from unmyelinated nerves to produce myelin: a quantitative ultrastructural and radiographic study. J Neurocytol 5:565-573. CrossRef Medline

Britsch S (2007) The neuregulin-I/ErbB signaling system in development and disease. Adv Anat Embryol Cell Biol 190:1-65. CrossRef Medline

Buggia-Prévot V, Fernandez CG, Udayar V, Vetrivel KS, Elie A, Roseman J, Sasse VA, Lefkow M, Meckler X, Bhattacharyya S, George M, Kar S, Bindokas VP, Parent AT, Rajendran L, Band H, Vassar R, Thinakaran G (2013) A function for EHD family proteins in unidirectional retrograde dendritic transport of BACE1 and Alzheimer's disease Abeta production. Cell Rep 5:1552-1563. CrossRef Medline

Cai H, Wang Y, McCarthy D, Wen H, Borchelt DR, Price DL, Wong PC (2001) BACE1 is the major beta-secretase for generation of Abeta peptides by neurons. Nat Neurosci 4:233-234. CrossRef Medline

Chami L, Checler F (2012) BACE1 is at the crossroad of a toxic vicious cycle involving cellular stress and beta-amyloid production in Alzheimer's disease. Mol Neurodegener 7:52. CrossRef Medline

Deng M, He W, Tan Y, Han H, Hu X, Xia K, Zhang Z, Yan R (2013) Increased expression of reticulon 3 in neurons leads to reduced axonal transport of beta site amyloid precursor protein-cleaving enzyme 1. J Biol Chem 288:30236-30245. CrossRef Medline

Falls DL (2003) Neuregulins: functions, forms, and signaling strategies. Exp Cell Res 284:14-30. CrossRef Medline

Fischbach GD (2007) NRG1 and synaptic function in the CNS. Neuron 54:495-497. CrossRef Medline

Fleck D, van Bebber F, Colombo A, Galante C, Schwenk BM, Rabe L, Hampel H, Novak B, Kremmer E, Tahirovic S, Edbauer D, Lichtenthaler SF, Schmid B, Willem M, Haass C (2013a) Dual cleavage of neuregulin 1 type III by BACE1 and ADAM17 liberates its EGF-like domain and allows paracrine signaling. J Neurosci 33:7856-7869. CrossRef Medline

Fricker FR, Antunes-Martins A, Galino J, Paramsothy R, La Russa F, Perkins J, Goldberg R, Brelstaff J, Zhu N, McMahon SB, Orengo C, Garratt AN, Birchmeier C, Bennett DL (2013) Axonal neuregulin 1 is a rate limiting but not essential factor for nerve remyelination. Brain 136:2279-2297. CrossRef Medline

Haney CA, Sahenk Z, Li C, Lemmon VP, Roder J, Trapp BD (1999) Heterophilic binding of L1 on unmyelinated sensory axons mediates Schwann cell adhesion and is required for axonal survival. J Cell Biol 146:11731184. CrossRef Medline

He W, Hu J, Xia Y, Yan R (2014) BACE1 regulates notch signaling by controlling the cleavage of Jag1 and Jag2. J Biol Chem 289:20630-20637. CrossRef Medline
Hitt BD, Jaramillo TC, Chetkovich DM, Vassar R (2010) BACE1-/- mice exhibit seizure activity that does not correlate with sodium channel level or axonal localization. Mol Neurodegener 5:31. CrossRef Medline

Hitt B, Riordan SM, Kukreja L, Eimer WA, Rajapaksha TW, Vassar R (2012) beta-Site amyloid precursor protein (APP)-cleaving enzyme 1 (BACE1)deficient mice exhibit a close homolog of L1 (CHL1) loss-of-function phenotype involving axon guidance defects. J Biol Chem 287:3840838425. CrossRef Medline

Holmes WE, Sliwkowski MX, Akita RW, Henzel WJ, Lee J, Park JW, Yansura D, Abadi N, Raab H, Lewis GD (1992) Identification of heregulin, a specific activator of p185erbB2. Science 256:1205-1210. CrossRef Medline

Hu X, Hicks CW, He W, Wong P, Macklin WB, Trapp BD, Yan R (2006) Bacel modulates myelination in the central and peripheral nervous system. Nat Neurosci 9:1520-1525. CrossRef Medline

Hu X, He W, Diaconu C, Tang X, Kidd GJ, Macklin WB, Trapp BD, Yan R (2008) Genetic deletion of BACE1 in mice affects remyelination of sciatic nerves. FASEB J 22:2970-2980. CrossRef Medline

Hu X, He W, Luo X, Tsubota KE, Yan R (2013) BACE1 regulates hippocampal astrogenesis via the Jagged1-Notch pathway. Cell Rep 4:40-49. CrossRef Medline

Hussain I, Powell D, Howlett DR, Tew DG, Meek TD, Chapman C, Gloger IS, Murphy KE, Southan CD, Ryan DM, Smith TS, Simmons DL, Walsh FS, Dingwall C, Christie G (1999) Identification of a novel aspartic protease (Asp 2) as beta-secretase. Mol Cell Neurosci 14:419-427. CrossRef Medline

Kamal A, Almenar-Queralt A, LeBlanc JF, Roberts EA, Goldstein LS (2001) Kinesin-mediated axonal transport of a membrane compartment containing beta-secretase and presenilin-1 requires APP. Nature 414:643648. CrossRef Medline

Kim DY, Carey BW, Wang H, Ingano LA, Binshtok AM, Wertz MH, Pettingell WH, He P, Lee VM, Woolf CJ, Kovacs DM (2007) BACE1 regulates voltage-gated sodium channels and neuronal activity. Nat Cell Biol 9:755-764. CrossRef Medline

Kim DY, Gersbacher MT, Inquimbert P, Kovacs DM (2011) Reduced sodium channel $\mathrm{Na}(\mathrm{v}) 1.1$ levels in BACE1-null mice. J Biol Chem 286: 8106-8116. CrossRef Medline

Kuhn PH, Koroniak K, Hogl S, Colombo A, Zeitschel U, Willem M, Volbracht C, Schepers U, Imhof A, Hoffmeister A, Haass C, Roßner S, Bräse S, Lichtenthaler SF (2012) Secretome protein enrichment identifies physiological BACE1 protease substrates in neurons. EMBO J 31:31573168. CrossRef Medline

La Marca R, Cerri F, Horiuchi K, Bachi A, Feltri ML, Wrabetz L, Blobel CP, Quattrini A, Salzer JL, Taveggia C (2011) TACE (ADAM17) inhibits Schwann cell myelination. Nat Neurosci 14:857-865. CrossRef Medline

Lazarov O, Morfini GA, Lee EB, Farah MH, Szodorai A, DeBoer SR, Koliatsos VE, Kins S, Lee VM, Wong PC, Price DL, Brady ST, Sisodia SS (2005) Axonal transport, amyloid precursor protein, kinesin-1, and the processing apparatus: revisited. J Neurosci 25:2386-2395. CrossRef Medline

Lemke G (2006) Neuregulin-1 and myelination. Sci STKE 2006:pe11. CrossRef Medline

Lin X, Koelsch G, Wu S, Downs D, Dashti A, Tang J (2000) Human aspartic protease memapsin 2 cleaves the beta-secretase site of beta-amyloid precursor protein. Proc Natl Acad Sci U S A 97:1456-1460. CrossRef Medline

Liu X, Bates R, Yin DM, Shen C, Wang F, Su N, Kirov SA, Luo Y, Wang JZ, Xiong WC, Mei L (2011) Specific regulation of NRG1 isoform expression by neuronal activity. J Neurosci 31:8491-8501. CrossRef Medline

Luo X, Prior M, He W, Hu X, Tang X, Shen W, Yadav S, Kiryu-Seo S, Miller R, Trapp BD, Yan R (2011) Cleavage of neuregulin-1 by BACE1 or ADAM10 protein produces differential effects on myelination. J Biol Chem 286:23967-23974. CrossRef Medline

Luo Y, Bolon B, Kahn S, Bennett BD, Babu-Khan S, Denis P, Fan W, Kha H, Zhang J, Gong Y, Martin L, Louis JC, Yan Q, Richards WG, Citron M, Vassar R (2001) Mice deficient in BACE1, the Alzheimer's betasecretase, have normal phenotype and abolished beta-amyloid generation. Nat Neurosci 4:231-232. CrossRef Medline

Mei L, Nave KA (2014) Neuregulin-ERBB signaling in the nervous system and neuropsychiatric diseases. Neuron 83:27-49. CrossRef Medline

Mei L, Xiong WC (2008) Neuregulin 1 in neural development, synaptic plasticity and schizophrenia. Nat Rev Neurosci 9:437-452. CrossRef Medline

Michailov GV, Sereda MW, Brinkmann BG, Fischer TM, Haug B, Birchmeier C, 
Role L, Lai C, Schwab MH, Nave KA (2004) Axonal neuregulin-1 regulates myelin sheath thickness. Science 304:700-703. CrossRef Medline

Nave KA, Salzer JL (2006) Axonal regulation of myelination by neuregulin 1. Curr Opin Neurobiol 16:492-500. CrossRef Medline

Park SK, Solomon D, Vartanian T (2001) Growth factor control of CNS myelination. Dev Neurosci 23:327-337. CrossRef Medline

Roberds SL, Anderson J, Basi G, Bienkowski MJ, Branstetter DG, Chen KS, Freedman SB, Frigon NL, Games D, Hu K, Johnson-Wood K, Kappenman KE, Kawabe TT, Kola I, Kuehn R, Lee M, Liu W, Motter R, Nichols NF, Power M, et al. (2001) BACE knockout mice are healthy despite lacking the primary beta-secretase activity in brain: implications for Alzheimer's disease therapeutics. Hum Mol Genet 10:1317-1324. CrossRef Medline

Sachse CC, Kim YH, Agsten M, Huth T, Alzheimer C, Kovacs DM, Kim DY (2013) BACE1 and presenilin/gamma-secretase regulate proteolytic processing of KCNE1 and 2, auxiliary subunits of voltage-gated potassium channels. FASEB J 27:2458-2467. CrossRef Medline

Selkoe DJ (1994) Alzheimer's disease: a central role for amyloid. J Neuropathol Exp Neurol 53:438-447. CrossRef Medline

Sinha S, Anderson JP, Barbour R, Basi GS, Caccavello R, Davis D, Doan M, Dovey HF, Frigon N, Hong J, Jacobson-Croak K, Jewett N, Keim P, Knops J, Lieberburg I, Power M, Tan H, Tatsuno G, Tung J, Schenk D, et al. (1999) Purification and cloning of amyloid precursor protein betasecretase from human brain. Nature 402:537-540. CrossRef Medline

Stassart RM, Fledrich R, Velanac V, Brinkmann BG, Schwab MH, Meijer D, Sereda MW, Nave KA (2013) A role for Schwann cell-derived neuregulin-1 in remyelination. Nat Neurosci 16:48-54. CrossRef Medline

Tanzi RE, Bertram L (2005) Twenty years of the Alzheimer's disease amyloid hypothesis: a genetic perspective. Cell 120:545-555. CrossRef Medline

Tao Y, Dai P, Liu Y, Marchetto S, Xiong WC, Borg JP, Mei L (2009) Erbin regulates NRG1 signaling and myelination. Proc Natl Acad Sci U S A 106:9477-9482. CrossRef Medline

Taveggia C, Zanazzi G, Petrylak A, Yano H, Rosenbluth J, Einheber S, Xu X, Esper RM, Loeb JA, Shrager P, Chao MV, Falls DL, Role L, Salzer JL (2005) Neuregulin-1 type III determines the ensheathment fate of axons. Neuron 47:681-694. CrossRef Medline

Taveggia C, Thaker P, Petrylak A, Caporaso GL, Toews A, Falls DL, Einheber
S, Salzer JL (2008) Type III neuregulin-1 promotes oligodendrocyte myelination. Glia 56:284-293. CrossRef Medline

Vassar R, Bennett BD, Babu-Khan S, Kahn S, Mendiaz EA, Denis P, Teplow DB, Ross S, Amarante P, Loeloff R, Luo Y, Fisher S, Fuller J, Edenson S, Lile J, Jarosinski MA, Biere AL, Curran E, Burgess T, Louis JC, et al. (1999) Beta-secretase cleavage of Alzheimer's amyloid precursor protein by the transmembrane aspartic protease BACE. Science 286:735-741. CrossRef Medline

Vassar R, Kovacs DM, Yan R, Wong PC (2009) The $\beta$-secretase enzyme BACE in health and Alzheimer's disease: regulation, cell biology, function, and therapeutic potential. J Neurosci 29:12787-12794. CrossRef Medline

Vassar R, Kuhn PH, Haass C, Kennedy ME, Rajendran L, Wong PC, Lichtenthaler SF (2014) Function, therapeutic potential and cell biology of BACE proteases: current status and future prospects. J Neurochem 130: 4-28. CrossRef Medline

Willem M, Garratt AN, Novak B, Citron M, Kaufmann S, Rittger A, DeStrooper B, Saftig P, Birchmeier C, Haass C (2006) Control of peripheral nerve myelination by the beta-secretase BACE1. Science 314: 664-666. CrossRef Medline

Wong HK, Sakurai T, Oyama F, Kaneko K, Wada K, Miyazaki H, Kurosawa M, De Strooper B, Saftig P, Nukina N (2005) beta Subunits of voltagegated sodium channels are novel substrates of beta-site amyloid precursor protein-cleaving enzyme (BACE1) and gamma-secretase. J Biol Chem 280:23009-23017. CrossRef Medline

Yan R, Vassar R (2014) Targeting the beta secretase BACE1 for Alzheimer's disease therapy. Lancet Neurol 13:319-329. CrossRef Medline

Yan R, Bienkowski MJ, Shuck ME, Miao H, Tory MC, Pauley AM, Brashier JR, Stratman NC, Mathews WR, Buhl AE, Carter DB, Tomasselli AG, Parodi LA, Heinrikson RL, Gurney ME (1999) Membrane-anchored aspartyl protease with Alzheimer's disease beta-secretase activity. Nature 402:533-537. CrossRef Medline

Zhou L, Barão S, Laga M, Bockstael K, Borgers M, Gijsen H, Annaert W, Moechars D, Mercken M, Gevaer K, De Strooper B (2012) The neural cell adhesion molecules L1 and CHL1 are cleaved by BACE1 protease in vivo. J Biol Chem 287:25927-25940. CrossRef Medline 